\title{
Behavioral evidence for host races in Rhagoletis pomonella flies
}

\author{
Ronald J. Prokopy ${ }^{1}$, Scott R. Diehl ${ }^{2}$, and Sylvia S. Cooley ${ }^{1}$ \\ ${ }^{1}$ Department of Entomology, University of Massachusetts, Amherst, MA 01003, USA \\ ${ }^{2}$ Department of Human Genetics, University of Michigan Medical School, Ann Arbor, MI 48109, USA
}

\begin{abstract}
Summary. One of the most controversial putative cases of host race formation in insects is that of the apple maggot fly, Rhagoletis pomonella (Diptera: Tephritidae). A principal cause of the controversy is lack of relevant data. In laboratory and field enclosure experiments, we compared the host acceptance behavior of sympatric populations of flies originating from naturally infested hawthorn (the native host) and apple (an introduced host) in Amherst, Massachusetts or East Lansing, Michigan. In general, hawthorn fruit were accepted for ovipositional attempts nearly equally by apple and hawthorn origin females, whereas apples were accepted much more often by apple than hawthorn origin females. Similarly, males of apple and hawthorn origin exhibited about equal duration of residence on hawthorn fruits as sites at which to acquire potential mates, while males of apple origin tended to reside substantially longer than males of hawthorn origin on apples. Irrespective of fly origin, both sexes always responded more positively to hawthorn fruit than to apples. Because all flies assayed were naive (ruling out effects of prior host experience of adults) and because tests revealed no influence of pre-imaginal fruit exposure on pattern of host fruit acceptance by females, the combined evidence suggests the phenotypic differences we observed in host response pattern between hawthorn and apple origin flies may have an underlying genetic basis. Further tests showed that while larval progeny of flies of each origin survived better in naturally growing hawthorn fruit than in naturally growing apples, there was no differential effect of fly origin on larval survival ability in either host. We discuss our findings in relation to restriction in gene flow between sympatric populations of $R$. pomonella and in relation to current models of host shifts in insects.
\end{abstract}

Key words: Rhagoletis - Host races - Oviposition behavior Larval survival

Over the past two decades, interest in processes of host race formation in insects has continued to grow. Evidence of host race formation in contemporary species has been examined by Mayr (1970), Bush (1975a), Futuyma and Mayr (1980), Jaenike (1981), Paterson (1981), Diehl and Bush (1984) Zwölfer and Bush (1984), and Futuyma and

Offprint requests to: R.J. Prokopy
Peterson (1985). Examples include a wide variety of parasitic and non-parasitic insects and other organisms utilizing plants or animals as food resources. Although a consensus on the definition of the term "host race" is lacking (Mayr 1970; Jaenike 1981; Diehl and Bush 1984), all current concepts emphasize host preference differences as being at least partially responsible for maintaining reproductive isolation among host races, irrespective of whether isolation is viewed as having arisen in allopatry, parapatry, or sympatry.

One of the most controversial putative cases of host race formation is that of the apple maggot, Rhagoletis pomonella (Walsh) (Bush 1966, 1974, 1975 b; Reissig and Smith 1978; Futuyma and Mayer 1980; Jaenike 1981; Paterson 1981; Prokopy et al. 1982a; Diehl 1984; Diehl and Bush 1984). $R$. pomonella is endemic to eastern North America, where it infests various native species of hawthorn (Crataegus). During the mid-19th century, its host range expanded to apple (Malus pumila), a domestic fruit that had been introduced to North America from Europe during the 17th century (Walsh 1867). Within the past few decades, $R$. pomonella has also formed persistent populations on sour cherry (Prunus cerasus var. Montmorency) (Shervis et al. 1970; Jorgensen et al. 1986) and rose (Rosa rugosa) (Prokopy and Berlocher 1980) and occasionally infests pear (Pyrus communis) (Prokopy and Bush 1972). All these hosts are in the family Rosaceae.

Two previous studies comparing behavioral responses of female $R$. pomonella assayed in groups hinted at small differences in the pattern of host fruit acceptance between hawthorn and apple origin flies from Nova Scotia (Prokopy and Bush 1973) and New York (Reissig and Smith 1978). Two rather recent cursory laboratory investigations (Prokopy et al. 1982a; Stanek et al. 1987), in which females were assayed individually, provided evidence suggesting differences in the pattern of host fruit acceptance (ovipositor boring attempts) between populations on hawthorn and apple in Massachusetts. On the other hand, Prokopy et al. (1985) found no differences in pattern of acceptance of a variety of fruit types among populations of $R$. pomonella originating from apple in Nova Scotia, Massachusetts, Michigan, and Oregon.

In addition to behavioral host-acceptance differences, utilization of different host plants sometimes also involves genetic differences influencing digestive physiology (Diehl and Bush 1984). Several studies were carried out in the 1930 's to assess the suitability of various host fruit for development of Rhagoletis pomonella larvae (Hall 1939, 1943; 
Pickett 1937; Pickett and Neary 1940). However, most of these used fruit that were removed from the tree, and it is now known that this increases larval survival rates above those experienced when the fruit remains naturally on the tree (Reissig 1979). More recently, Reissig and Smith (1978) reported very similar rates of egg hatching in reciprocal crosses of hawthorn and apple origin flies from New York, indicating reproductive compatibility at least to this early stage of development.

Here, we present results of extensive laboratory and field cage experiments comparing host acceptance behavior of $R$. pomonella females reared from naturally infested hawthorn and apple. In addition, the possibility of preimaginal conditioning (Diehl and Bush 1984) of host acceptance behavior of females by the larval host fruit environment was evaluated in laboratory tests using flies reared from naturally infested pear and rose. When considering gene flow between populations associated with different hosts, male host selection behavior is just as important as female behavior in sexually reproducing species. Therefore, we also investigated the response of males of hawthorn and apple origin to hawthorn and apple fruit. Finally, we report results of tests of the suitability of unpicked apple and hawthorn fruit for development from egg to pupal stages by progeny of flies of hawthorn and apple origin.

\section{Materials and methods}

All flies tested originated from puparia formed by larvae collected from naturally infested fruit. Prior to testing, both sexes were maintained together after eclosion in laboratory cages as described previously (Diehl and Prokopy 1986). All flies were assayed between 12-23 days post-eclosion, when all males and most females were sexually mature and presumably mated. We have previously shown that the degree to which females accept hosts may change significantly across this age range (Stanek et al. 1987). Therefore, fly ages were closely matched for populations being compared in each experiment. To preclude any influence of prior adult experience with fruit on the host-acceptance response (Prokopy et al. 1982 b, 1986), all flies were naive when assayed (i.e., without previous exposure to any fruit).

Laboratory assays of female host-acceptance. Single-hostpresentation assays of female host acceptance behavior were carried out in an indoor laboratory setting as described previously in detail (Diehl and Prokopy 1986). Briefly, each fly was placed individually on a test fruit and allowed to remain on the fruit for two consecutive five-minute periods. A fly was scored as "accepting" the test fruit if it attempted to puncture the fruit with its ovipositor during one of these periods or scored as "rejecting" the fruit otherwise. Thus, the fly's behavior was categorized as a discrete (binary) response. In all experiments, fruits tested were Red Delicious apple (avg $=57 \mathrm{~mm}$ diam, range $52-62 \mathrm{~mm}$ ) and $C$. mollis hawthorn (avg $=15 \mathrm{~mm}$ diam, range $13-17 \mathrm{~mm}$ ). They had been collected from unsprayed, highly isolated, uninfested sites 6-9 months before use and stored at $3^{\circ} \mathrm{C}$. All were washed and warmed to $26^{\circ} \mathrm{C}$ prior to testing. To minimize uncontrolled environmental variation, we assayed successively no more than two individuals from one population before assaying individuals from another population. We tested each fruit type in each possible order of presentation for an approximately equal number of individuals of each fly population. We offered each individual fruit specimen an approximately equal number of times (usually no more than three) to flies of each population.

Two sets of sympatric populations originating from different naturally infested hosts were compared using this laboratory assay. In 1983, we tested flies collected in 1981 in Amherst, MA from C. mollis hawthorn and a mixture of apple varieties. The trees bearing these fruit types were located $1.6 \mathrm{~km}$ apart. In 1984 , we tested flies collected in 1983 from these same sites. In 1985, we tested flies collected in 1983 from C. mollis hawthorn and McIntosh apples in East Lansing, MI. The trees bearing these fruit types were located $2.0 \mathrm{~km}$ apart. To assess whether female size might influence host-acceptance behavior, flies from a random sample of non-assayed individuals in 1983 were dried at ca. $35^{\circ} \mathrm{C}$ for one week and weighed.

In mixed-host-presentation assays, the host-acceptance behavior of hawthorn and apple origin flies from Amherst, MA (collected in 1983) were tested in 1984 using a laboratory assay similar to the above, but with hawthorn and apple fruits present simultaneously. Females (15-19 days old) were introduced individually into a cage containing three C. mollis hawthorns and three Red Delicious apples. The flies were allowed to move freely between these fruit until they attempted ovipositor boring into either kind of fruit or until five min had elapsed. Data for flies that visited only one fruit type were analyzed separately from data for flies that visited both types.

Preimaginal conditioning of female host acceptance. Preimaginal conditioning would occur if the host acceptance behavior of flies were altered as a consequence of larval development in different host fruits, without any genetic changes due to differential mortality in the different hosts. Parent $R$. pomonella flies reared from naturally infested rose $(R$. rugosa) collected in Falmouth, MA in 1981 were used in one replicate of the experiment, while flies reared from pear collected in Amherst, MA in 1982 were used in the other replicate. Parent adults were permitted to oviposit 1-2 eggs in each C. mollis hawthorn and ca. 10 eggs in each Red Delicious apple. These fruit had been picked from unsprayed sites near Amherst, MA early in the season of the preceding summer and stored at $3^{\circ} \mathrm{C}$ for several months, which killed any larvae present in the fruit prior to use (Chapman 1933). Progeny larvae were reared to pupation under identical conditions in the laboratory. Upon eclosion, progeny adults were held in laboratory cages as described previously (Diehl and Prokopy 1986). The host-acceptance responses of 12-19 day old progeny females were then assayed in single-host-presentation tests using the laboratory method described above.

Field cage assays of female host acceptance. We further compared the Amherst, MA hawthorn and apple origin flies in field cage assays. These tests were conducted outdoors in Amherst, MA in 1983, using flies reared from fruit collected in 1981. An individual female was transferred gently to a vigorously growing, potted, ca. $2 \mathrm{~m}$ tall $\times 1.5 \mathrm{~m}$ diam C. brachyacantha var. toba hawthorn tree enclosed in a cylindrical saran-screen field cage $(3 \mathrm{~m}$ tall $\times 3.5 \mathrm{~m}$ diam, $11.5 \mathrm{~mm}$ mesh, with a dark cloth above the cage ceiling). The fly was placed onto the upper surface of a leaf at the bottom-central portion of the tree ( $R$. pomonella females 
foraging within host trees generally make a series of short upward flights until a fruit is found (Roitberg et al. 1982)). To minimize effects on fly foraging behavior due to temperature (Diehl and Prokopy, unpublished data), we alternated testing of hawthorn and apple origin flies.

In the single-host-presentation field cage test, either 16 C. mollis hawthorns or 16 Red Delicious apples were hung uniformly throughout the tree. In this test, 12-16 day old females were permitted to forage in the tree up to ten min. If a fly did not visit any fruit within ten min or flew out of the tree to the cage wall during this period, the replicate was terminated. Those females which did visit a fruit were allowed to remain on the fruit up to five min. Those which attempted ovipositor boring during this time were categorized as "accepting" the fruit. Those either leaving the fruit or remaining five min without attempting ovipositor boring were considered to have "rejected" the fruit. The experiment was terminated after the first visit to a fruit.

In the mixed-host-presentation field cage test, a mixture of eight $C$. mollis hawthorns and eight Red Delicious apples was hung throughout the tree. The procedure used was otherwise identical to the above except females were permitted to visit successive fruit until they "accepted" a fruit, remained on a fruit five min without accepting it, or failed to visit any fruit within ten min of the last fruit visit.

Male host-response behavior. The behavior of male $R$. pomonella responding to $C$. mollis hawthorn and Red Delicious apple fruit was examined in laboratory assays in 1984 and 1985. The apple origin flies were reared from naturally infested fruit collected in 1983 and 1984 at the same site in Amherst, MA as for the preceding tests of females. $C$. mollis hawthorn origin flies were reared from naturally infested fruit collected in Northampton, MA (ca. $11 \mathrm{~km}$ from Amherst). Most flies were tested 8-12 days post-eclosion, but some were tested 20-27 days post-eclosion. Male behavior in response to hawthorn and apple fruit was assayed by gently transferring an individual fly onto a single hawthorn or apple fruit in a laboratory cage, just as was done in the laboratory assays of female host-acceptance behavior. The duration of time the fly remained on the fruit (up to a maximum of $15 \mathrm{~min}$ ) was recorded. After leaving the fruit or at the expiration of the $15 \mathrm{~min}$ period, the fly was left in the cage without fruit for $2-3 \mathrm{~min}$, then tested in the same manner on the other fruit type. The presentation order for testing each fruit (i.e., hawthorn or apple tested first) and the host origin of the flies tested (hawthorn or apple) were alternated throughout the experiment.

Larval survival in different host fruits. We assessed proportions of eggs laid by flies of hawthorn and apple origin surviving to the pupal stage when naturally oviposited or artificially inserted into $C$. mollis hawthorn versus McIntosh apple fruit. These fruit were growing naturally on trees in Amherst, MA. All flies used in these tests were reared from naturally infested hawthorn or apple fruit collected in 1983 or 1984 in Amherst, MA (sites described above). Females were held in laboratory cages with males until 12-20 days after eclosion, at which time most were sexually mature and had mated with one or more males. Individual females were then isolated in small cages after clipping their wings to prevent escape. To determine whether the flies used in this experiment had mated at least once, each female was permitted to lay eggs into wax domes. These eggs were transferred to moist filter paper, where hatching took place within five days if the female had mated. Eggs laid by unmated females do not hatch (Opp and Prokopy 1986). It should be noted that since complete sperm precedence has not been found in $R$. pomonella (Opp and Prokopy, unpublished data), it is safe to assume that each female's progeny consisted of a mixture of full and maternal half siblings.

Two methods were used to deposit eggs into fruit. In 1984, females were taken outdoors to apple or hawthorn fruit growing naturally on trees and allowed to lay one to three eggs per apple or a single egg per hawthorn fruit. Observation of ovipositor penetration followed by pheromone-marking of the fruit was used to determine that an egg had been laid inside the fruit (unobservable without destructive sampling). Previous studies have shown that flies do not always lay eggs when boring into fruit with the ovipositor, but egg deposition is highly likely (ca. $90 \%$ probability of occurrence) when such boring is followed by pheromone marking (Prokopy 1972). In 1985, eggs were collected from females by allowing them to oviposit into wax domes. These eggs were then inserted manually into fruit using a sterile needle, after which the external puncture was sealed with plastic tape.

At the time of egg insertion, all fruit utilized were in a stage suitable for development of apple maggot larvae (pre-ripe, 3-4 weeks before abscission). They had been protected from attack by wild $R$. pomonella by covering with mosquito netting early in the season. Due to differences between McIntosh apple and $C$. mollis hawthorn fruit in stage of maturity and due to the flies' limited longevity and fertility periods, it was feasible to test the survival of eggs laid by an individual only either in apple or hawthorn (not both fruit). After egg deposition, the fruit was numbered to identify the individual laying the $\operatorname{egg}(\mathrm{s})$, re-covered with mosquito netting, and allowed to remain on the tree until abscission occurred. Thrice weekly, abscissed fruit were collected. Those belonging to the same female were grouped together and held over moist vermiculite for one month, by which time all surviving larvae had pupated in the vermiculite. The vermiculite was then sifted, and the number of pupae obtained from each sibship was recorded. Proportions of eggs surviving to the pupal stage were compared among a total of 96 sibships (936 eggs). The balanced design consisted of groups of 12 sibships (undeterminable mixtures of full and half sibs) nested within fly origin (hawthorn and apple), test host (hawthorn and apple), and year tested (1984 and 1985).

Data analysis. The proportions of individually assayed females of each population that visited or "accepted" (attempted ovipositor boring into) hawthorn and apple test fruit were compared statistically using a multidimensional logistic regression technique appropriate for such categorical data (Grizzle et al. 1969; Koch et al. 1982; Stanek et al. 1987), implemented by the program CATMOD (SAS 1985). This multidimensional approach to categorical data analysis allows both main effects and interactions to be assessed, as in the Analysis of Variance model for continuous data. The same approach was used in analyzing data on larval survival in different host fruit. For making paired comparisons, we employed Goodman's method (Goodman 1964) for multiple contrasts (when analyzing female host acceptance response or larval survival) or Mann-Whitney $U$ tests (when analyzing male host residence response). 
Table 1. Laboratory assays of host-acceptance behavior of individually tested $R$. pomonella females originating from and tested on hawthorn or apple fruit in single and mixed test host assays

\begin{tabular}{|c|c|c|c|c|c|c|c|c|}
\hline \multirow[t]{3}{*}{ Type of assay } & \multirow[t]{3}{*}{ Year of assay } & \multirow[t]{3}{*}{ Site of origin } & \multirow[t]{3}{*}{ Host of origin } & \multirow{2}{*}{\multicolumn{2}{|c|}{$\begin{array}{l}\% \text { accepting test fruit } \\
(n \text { flies })^{\mathrm{a}}\end{array}$}} & \multicolumn{3}{|c|}{ Logistic Regression Statistics ${ }^{b}$} \\
\hline & & & & & & \multirow{2}{*}{$\begin{array}{l}\text { Host } \\
\text { origin }\end{array}$} & \multirow{2}{*}{$\begin{array}{l}\text { Test } \\
\text { fruit }\end{array}$} & \multirow{2}{*}{$\begin{array}{l}\text { Host Origin } \\
\times \text { Test Fruit }\end{array}$} \\
\hline & & & & Hawthorn & Apple & & & \\
\hline \multirow[t]{3}{*}{ Single host } & 1983 & Mass. & $\begin{array}{l}\text { Hawthorn } \\
\text { Apple }\end{array}$ & $\begin{array}{l}75(81) \mathrm{a} \\
79(82) \mathrm{a}\end{array}$ & $\begin{array}{l}11(81) c \\
33(82) b\end{array}$ & $7.9(1)^{* *}$ & $85.5(1)^{* * *}$ & $4.1(1)^{*}$ \\
\hline & 1984 & Mass. & $\begin{array}{l}\text { Hawthorn } \\
\text { Apple }\end{array}$ & $\begin{array}{l}88(52) \mathrm{a} \\
87(60) \mathrm{a}\end{array}$ & $\begin{array}{l}17(52) \mathrm{c} \\
43(60) \mathrm{b}\end{array}$ & $2.4(1)$ & $61.6(1)^{* *}$ & $4.0(1)^{*}$ \\
\hline & 1985 & Mich. & $\begin{array}{l}\text { Hawthorn } \\
\text { Apple }\end{array}$ & $\begin{array}{l}68(41) \mathrm{a} \\
78(18) \mathrm{a}\end{array}$ & $\begin{array}{r}5(41) \mathrm{c} \\
22(18) \mathrm{b}\end{array}$ & $3.8(1)$ & $30.4(1)^{* * *}$ & $1.2(1)$ \\
\hline \multirow[t]{2}{*}{ Mixed hosts } & 1984 & Mass. & $\begin{array}{l}\text { Hawthorn-1 } \\
\text { Apple-1 }\end{array}$ & $\begin{array}{l}88(16) a \\
92(26) a\end{array}$ & $\begin{array}{l}28(72) b \\
35(71) b\end{array}$ & $0.3(1)$ & $40.6(1)^{* * *}$ & $0.0(1)^{d}$ \\
\hline & & & $\begin{array}{l}\text { Hawthorn-2 } \\
\text { Apple-2 }\end{array}$ & $\begin{array}{l}58(19) \mathrm{a} \\
54(13) \mathrm{a}\end{array}$ & $\begin{array}{l}4(25) b \\
5(19) b\end{array}$ & & & \\
\hline
\end{tabular}

a Values in each experiment (year of assay) followed by the same letter are not significantly different at the 0.05 level according to Goodman's method for multiple contrasts

${ }^{b}$ Wald statistic (degrees of freedom)

c Data presented separately for flies which visited one (1) or both (2) hosts

${ }^{d}$ Wald statistics of all other interactions were $<0.2$

* $P<0.05, * * P<0.01, * * * P<0.001$

\section{Results}

\section{Adult host-acceptance behavior}

Hawthorn fruit consistently were accepted more often for ovipositor boring by females of both origins than were apples, in both single and mixed host laboratory assays (Table 1). The significant paired comparison values (Goodman's method) and the significant values for Test Fruit effects (logistic regression) support this conclusion. In the single host assays, apple origin females showed about the same propensity as hawthorn origin females to accept hawthorn fruit in all three tests, but showed significantly greater propensity than hawthorn origin females to accept apple in all three tests. In one of these tests, there was a significant Host Origin effect, indicative of greater acceptance of both test fruits by apple origin than hawthorn-origin females. The Host Origin $\times$ Test Fruit interaction term was significant in two of the three tests. Within the context of our data, a significant interaction of this sort indicates greater propensity of apple origin females than hawthorn origin females to accept apples, but equal or lesser propensity of apple origin females compared with hawthorn origin females to accept hawthorn. In the mixed host assay, there were no significant differences between females of different host origin in fruit acceptance pattern, nor were interaction effects significant. A $t$ test was performed on the dry weights of a random sample of non-assayed hawthorn and apple origin flies ( $n$ flies $=27$ and 31 , respectively) from populations and in the 1983 single host test. No significant differences were found between the weights of these two groups $(X=3.43 \pm$ S.E. $0.13 \mathrm{mg}$ for hawthorn origin females versus $3.17 \pm$ S.E. $0.11 \mathrm{mg}$ for apple origin females; $t=1.39, p>$ $0.05)$. This indicates no detectable influence of female size on pattern of host acceptance.

There was no evidence of an effect on female host-acceptance due to preimaginal conditioning as a result of larval rearing in different fruits (Table 2). The results of this exper-
Table 2. Laboratory assays of preimaginal conditioning effects on host acceptance behavior of individually tested $R$. pomonella females due to larval rearing on hawthorn versus apple fruit. The parents of the test flies originated from naturally infested rose or pear fruit

\begin{tabular}{|c|c|c|c|}
\hline \multirow[t]{2}{*}{ Host of Origin } & \multirow[t]{2}{*}{ Rearing Host } & \multicolumn{2}{|c|}{$\%$ accepting test fruit ( $n$ flies) } \\
\hline & & Hawthorn & Apple \\
\hline \multirow[t]{2}{*}{ Rose } & Hawthorn & $80(51) \mathrm{b}$ & $17(102) \mathrm{c}$ \\
\hline & Apple & $91(106) \mathrm{a}$ & $24(212) \mathrm{c}$ \\
\hline \multirow[t]{2}{*}{ Pear } & Hawthorn & $86(89) a$ & $39(168) b$ \\
\hline & Apple & 89 (53)a & $38(106) \mathrm{b}$ \\
\hline \multicolumn{4}{|c|}{ Logistic Regression Statistics ${ }^{b}$} \\
\hline Host origin & Test fruit & Rearing host & $\begin{array}{l}\text { Host origin } \\
\times \text { Test fruit }\end{array}$ \\
\hline $5.7(1)^{*}$ & $185.4(1)^{* * *}$ & $3.5(1)$ & $3.9(1)^{* c}$ \\
\hline
\end{tabular}

a Values in each experiment (host of origin) followed by the same letter are not significantly different at the 0.05 level according to Goodman's method for multiple contrasts

b Wald statistic (degrees of freedom)

$c$ Wald statistics of all other interactions were $<1.8$

${ }^{*} P<0.05, * * * P<0.001$

iment again strongly indicated that hawthorn is a significantly more acceptable fruit than apple. Evidence also indicated that the response pattern of progeny of pear origin flies was similar to that of apple origin flies seen in other tests (i.e. relatively high acceptance of apples), while the response pattern of progeny of rose origin flies was similar to that of hawthorn origin flies seen in other tests.

Assays carried out in field cages on a single tree indicated flies were much more likely to visit apples than hawthorn fruit in both single and mixed host assays, probably on account of the larger size of apple fruit (Prokopy 1977) 
Table 3. Field cage assays of host acceptance behavior of individually tested $R$. pomonella females originating from and tested on hawthorn and apple fruit in single and mixed test host assays

\begin{tabular}{|c|c|c|c|c|c|c|}
\hline \multirow[t]{2}{*}{ Type of assay } & \multirow[t]{2}{*}{ Host of origin } & \multicolumn{2}{|l|}{ Test Fruit } & \multicolumn{3}{|c|}{ Logistic Regression Statistics ${ }^{b}$} \\
\hline & & Hawthorn & Apple & Host origin & Test fruit & $\begin{array}{l}\text { Host Origin } \\
\times \text { Test fruit }\end{array}$ \\
\hline \multicolumn{7}{|c|}{$\%$ visiting a test fruit ( $n$ flies) ${ }^{a}$} \\
\hline Single host & $\begin{array}{l}\text { Hawthorn } \\
\text { Apple }\end{array}$ & $\begin{array}{l}42(60) \mathrm{b} \\
68(37) \mathrm{a}\end{array}$ & $\begin{array}{l}81(43) a \\
81(43) a\end{array}$ & $2.3(1)$ & $13.1(1)^{* * *}$ & $2.3(1)$ \\
\hline \multicolumn{7}{|c|}{$\%$ accepting test fruit ( $n$ flies) } \\
\hline & $\begin{array}{l}\text { Hawthorn } \\
\text { Apple }\end{array}$ & $\begin{array}{l}64(25) \mathrm{a} \\
84(25) \mathrm{a}\end{array}$ & $\begin{array}{r}3(35) \mathrm{c} \\
26(35) \mathrm{b}\end{array}$ & $6.8(1)^{* *}$ & $21.4(1)^{* * *}$ & $1.7(1)$ \\
\hline \multicolumn{7}{|c|}{$\%$ visiting a test fruit ${ }^{c}$} \\
\hline Mixed host & $\begin{array}{l}\text { Hawthorn } \\
\text { Apple }\end{array}$ & $\begin{array}{l}14 b \\
14 b\end{array}$ & $\begin{array}{l}86 a \\
86 a\end{array}$ & $0.0(1)$ & $55.6(1)^{* * *}$ & d \\
\hline \multicolumn{7}{|c|}{$\%$ accepting test fruit ( $n$ flies) } \\
\hline & $\begin{array}{l}\text { Hawthorn } \\
\text { Apple }\end{array}$ & $\begin{array}{l}90(10) \mathrm{a} \\
90(10) \mathrm{a}\end{array}$ & $\begin{array}{r}2(60) \mathrm{c} \\
18(61) \mathrm{b}\end{array}$ & $2.4(1)$ & $26.9(1)^{* * *}$ & $0.7(1)$ \\
\hline
\end{tabular}

a Values in each experiment followed by the same letter are not significantly different at the 0.05 level according to Goodman's method for multiple contrasts

b Wald statistic (degrees of freedom)

c Total number of fruit visits: Hawthorn origin flies $=70$, Apple origin flies $=71$

d Statistic not applicable to this assay

** $P<0.01, * * * P<0.001$

Table 4. Laboratory assays of host response behavior of individually tested $R$. pomonella males originating from and tested on hawthorn and apple fruit in single test host assays

\begin{tabular}{llll}
\hline Age of flies $^{\mathbf{b}}$ & Host of origin & \multicolumn{2}{l}{ Mean time on test fruit (sec) } \\
\cline { 3 - 4 } & & Hawthorn & Apple \\
\hline $8-12$ & Hawthorn & $472(80) \mathrm{a}$ & $164(80) \mathrm{c}$ \\
& Apple & $502(82) \mathrm{a}$ & $272(82) \mathrm{b}$ \\
$20-27$ & Hawthorn & $435(23) \mathrm{a}$ & $62(23) \mathrm{c}$ \\
& Apple & $559(13) \mathrm{ab}$ & $151(13) \mathrm{bc}$ \\
\hline
\end{tabular}

a Values in each age group followed by the same letter are not significantly different according to a Mann-Whitney $U$ test at the 0.05 level

b Fly ages are days post-eclosion

(Table 3). After fly arrival on a fruit, hawthorn was again much more likely to elicit ovipositor boring. As in the single host laboratory assays, apple origin flies were about equally prone to bore into hawthorn fruit but significantly more prone to bore into apples compared with hawthorn origin flies. The Host Origin $\times$ Test Fruit interaction term was not significant in either field cage assay, however, possibly owing to the relatively low number of flies visiting hawthorn.

Laboratory tests of males provided results strikingly similar in pattern to those obtained with females, despite the fundamentally different nature of the response being assayed (Table 4). Males of both larval origins remained on hawthorn fruit significantly longer than on apples. Both young and old apple origin males remained about equally as long on hawthorns as hawthorn origin males, while young apple origin males remained significantly longer on apples than young hawthorn origin males.
Table 5. Survival from egg to pupal stage of progeny of hawthorn or apple origin flies, reared in hawthorn or apple fruit

\begin{tabular}{llll}
\hline Year of assay & Host of origin & \multicolumn{2}{l}{$\begin{array}{l}\text { \% eggs }(n) \\
\text { surviving to pupal stage in }{ }^{\mathrm{a}}\end{array}$} \\
\cline { 3 - 4 } & & Hawthorn & Apple \\
\hline 1984 & Hawthorn & $70(86) \mathrm{b}$ & $61(88) \mathrm{bc}$ \\
1985 & Apple & $85(98) \mathrm{a}$ & $53(92) \mathrm{c}$ \\
& Hawthorn & $52(142) \mathrm{a}$ & $29(142) \mathrm{b}$ \\
& Apple & $52(151) \mathrm{a}$ & $25(137) \mathrm{b}$ \\
\hline
\end{tabular}

Logistic Regression Statistics

\begin{tabular}{lllll}
\hline Test fruit & $\begin{array}{l}\text { Year } \\
\text { of assay }\end{array}$ & Sibship & $\begin{array}{l}\text { Host } \\
\text { origin } \\
\times \text { Rearing } \\
\text { fruit }\end{array}$ & $\begin{array}{l}\text { Host origin } \\
\times \text { Rearing } \\
\text { fruit } \\
\times \text { Year } \\
\text { of assay }\end{array}$ \\
\hline $28.4(1)^{* * * c}$ & $59.8(1)^{* * *}$ & $167.9(88)^{* * *}$ & $3.7(1)$ & $2.8(1)$ \\
\hline
\end{tabular}

a Values in each year followed by the same letter are not significantly different at the 0.05 level according to Goodman's method for multiple contrasts

$b$ Wald statistics for other main effects and interactions were $<1.5$

- Wald statistic (degrees of freedom)

$* * * P<0.001$

\section{Larval survival in different host fruits}

Survival from egg to pupal stages was significantly higher for flies of both host origins in hawthorn than apple fruit in both 1984 and 1985 (Table 5). Overall survival was much higher in 1984 than 1985, but this could reflect either yearly differences in fruit quality, differences in egg density, differ- 
ences in the methods used to insert eggs into fruit, or a combination of these. Most striking was the very strong degree of differentiation among different sibships within both the hawthorn and apple fly populations. After taking the sibship variable into account in the multidimensional categorical data analysis (Table 5), no evidence of differences in survival rates was found between flies of different origins.

\section{Discussion}

As proposed by Bush (1974, 1975a, b), Jaenike (1981), Bush and Diehl (1982), Diehl and Bush (1984), Futuyma and Peterson (1985) and others, a constellation of factors may give rise to and/or promote the maintenance of host races in herbivorous insects. These may include (a) geneticallybased differences between conspecific populations in host plant preference, (b) positive assortative mating that arises as a consequence of confinement of mating initiation to host plants and the coupling of mate choice with genetically-based host plant choice, (c) fidelity to a particular host via effects of larval or adult experience, (d) differences among hosts that may affect survival ability and (e) temporal differences in host availability that may influence timing of entry into and emergence from diapause.

The results reported here provide evidence suggestive of a possible genetically-based difference in host fruit acceptance (- propensity to initiate ovipositor boring) among different host-associated populations of $R$. pomonella females. Thus, for the two experiments conducted on Amherst, MA flies under single-host-presentation conditions in the laboratory (Table 1) and for the two experiments carried out with Amherst flies on host trees in field cages (Table 3), invariably apple fruit were accepted by a significantly greater proportion of females originating from apples than by females originating from hawthorn (average over all four experiments $=30$ vs. $8 \%$ acceptance, respectively). On the other hand, hawthorn fruit in these same four experiments were accepted nearly equally (no case of a significant difference) by apple-origin and hawthorn-origin females ( 86 vs $79 \%$, respectively). The statistical significance of the interaction value of Host Origin $\times$ Test Fruit main effects in two of these four experiments further supports the conclusion that some proportion of females originating from these two hosts in Amherst differs in pattern of host fruit acceptance. A pattern of similar sort was manifest by East Lansing, MI females tested under single host conditions in the laboratory (Table 1) but not by Amherst females tested under mixed host conditions in the laboratory (Table 1 ).

The latter result should not be taken as cause to doubt the validity of findings under single host presentation conditions because in nature, fly encounter with a single fruit type on a plant is the norm, whereas fly encounter with mixed fruit types on a plant would be an extremely rare event, ocurring only when two plants of different type were intertwined. When we pooled the host-acceptance results of the three single-host laboratory assays (Table 1) and the one single-host field cage assay (Table 3) to evaluate Host Origin $\times$ Test Fruit interaction effects using Fishers's (1954) method of combining probabilities, the analysis yielded a statistic of 18.2 ( $8 \mathrm{df}$ ) that is distributed as chi-square with $\mathrm{P}<0.025$. Thus, we conclude that the overall Host Origin $x$ Test Fruit interaction effect in single host assays is statisti- cally significant. This conclusion is further supported by the results of more cursory tests given in Prokopy et al. (1982a) and Stanek et al. (1987) mentioned in the Introduction.

Because (a) all females assayed here were naive (no prior experience with fruit), (b) evidence indicated absence of any pre-imaginal fruit-exposure effect on pattern of host fruit acceptance (Table 2), and (c) Amherst hawthorn-origin females were consistently less inclined to accept apples than were Amherst apple-origin females, irrespective of fly age (only the magnitude of difference varied with age (Stanek et al. 1987)), we conclude that the phenotypic differences in host acceptance pattern between the apple and hawthorn origin flies tested here may have an underlying genetic basis. A firm conclusion, however, awaits quantitative genetic analyses of flies of apple and hawthorn origin, with estimates of heritability of acceptance behavior.

With respect to mating behavior, previous work revealed that at a Wisconsin field study site, $R$. pomonella initiated mating exclusively on host plants (Prokopy et al. 1971). Early in the fruiting season, when most $R$. pomonella females are virgin, sexual encounters have been observed on host plant foliage (Smith and Prokopy 1980). With the onset of oviposition, however, sexual encounters virtually cease to occur on the foliage and take place almost exclusively on the host fruit, where males force-copulate with unsuspecting females engaged in egglaying behavior (Prokopy et al. 1971; Smith and Prokopy 1980). Males may spend up to $90 \%$ of their time residing on or patrolling fruit. The data presented here (Table 4) on host response (=time of residence on fruit) of Amherst apple and hawthorn males parallel very closely in pattern the data on host acceptance by Amherst females tested under similar single-host conditions in the laboratory. Because all males were assayed when naive (hence ruling out prior experience with fruit as a factor) and because both young and older males responded similarly, we believe that as with the females, the phenotypic difference in host response pattern between Amherst apple and hawthorn origin males likewise may have an underlying genetic basis (we did not, however, test for effects of pre-imaginal fruit exposure on male behavior). We conclude, therefore, that because initiation of mating is confined to host plants and because both males and females appear to exhibit parallel population-origin differences in host plant selection, host-associated positive assortative mating, as argued by Bush and Diehl (1982), must be considered a potential force in maintaining differences in host preference.

The ability of $R$. pomonella larvae to survive and grow in host fruit undoubtedly depends on presence of suitable nutrients and on absence of deleterious plant secondary compounds (Pree 1977). Because apple and hawthorn trees are rosaceous plants, presumably their fruit possess several nutrients and secondary compounds in common, though to our knowledge, no one has yet compared apple and hawthorn fruit in this regard. Our finding that survival of $R$. pomonella from the egg to the pupal stage was substantially greater in hawthorn than apple fruit suggests important nutritional or secondary-compound differences do, however, exist between fruit of these plant genera. Whatever the nature of these differences, they affected larval progeny of Amherst apple and hawthorn origin flies equally. We found no evidence indicating $R$. pomonella larvae of Amherst apple origin are more likely to survive in apple fruit 
than are larvae of Amherst hawthorn origin, nor any evidence indicating larvae of hawthorn origin are more likely to survive in hawthorn fruit than are larvae of apple origin. Hence, our results do not support a hypothesis that larval progeny of Amherst apple and hawthorn populations differ in ability to survive on apple and hawthorn fruit. However, we did find evidence suggesting that variation in survival ability exists within each of these populations.

Together, the results of our host response assays of female and male $R$. pomonella suggest the existence of some degree of restriction in gene flow between a population on apple and a population on hawthorn in Amherst and very likely also between a population on apple and a population on hawthorn in East Lansing. In both locales, the two host-associated populations can be considered sympatric because individuals were probably within cruising range of one-another's host plants. This presumption is based on work by Maxwell and Parsons (1968), who found some $R$. pomonella flies capable of moving at least $1.6 \mathrm{~km}$ under field conditions.

To address how gene flow between these sympatric populations might be restricted, we must consider not only the traits examined here but also the entire repertoire of fly behavior involved in host selection. This includes host finding as well as host examining and acceptance behavior (Miller and Strickler 1984). Of particular interest to us is an explanation of how gene flow is restricted in face of the ability of both apple and hawthorn origin flies to accept hawthorn to an equal degree. The existence of populations that have shifted onto a new host but still show preference for the ancestral host is not unique to $R$. pomonella. It has been observed in several other herbivorous species (eg. Futuyma et al. 1984; Robert 1985).

In finding potential host fruit for egglaying, $R$. pomonella females are known to respond to the following stimuli: attractive fruit volatiles (Prokopy et al. 1973, 1987; Fein et al. 1982; Carle et al. 1987); plant color, form and size (Moericke et al. 1975); leaf architecture and/or chemistry, influencing within-plant search effort (Diehl 1984; Diehl et al. 1986 and unpublished data); the form, size and color of individual fruit that elicit attraction from close range (Prokopy 1968, 1977; Owens and Prokopy 1986; Prokopy et al. 1987); contact fruit stimuli (shape, size, color, surface structure and chemical factors) that elicit fruit "acceptance" (ovipositor boring attempts) and oviposition (Prokopy 1966; Diehl and Prokopy 1986; Papaj and Prokopy 1986; Girolami et al. 1986); and pheromone deposited on the fruit surface after egglaying that deters repeated oviposition (Prokopy 1981). Also, prior ovipositional experience can significantly affect the degree to which familiar and novel fruit are accepted or rejected in subsequent fruit visits (Prokopy et al. 1982b, 1986; Papaj and Prokopy 1986). The combined evidence from these studies suggests that in addition to differences shown here in post-alighting response of different populations of $R$. pomonella to fruit chemical or physical stimuli that elicit fruit boring attempts (for females) or fruit residence (for males), differences leading to restriction in gene flow between apple and hawthorn origin flies could conceivably exist in three other behavioral traits during the host selection process: response to host fruit odor cues in finding fruit-bearing trees; response to tree geometry or foliar chemistry or morphology during withintree examination; and response to fruit flesh properties following insertion of the ovipositor.
Given the evidence presented here suggesting $R$. pomonella may have formed host races on apple and hawthorn trees in Amherst and East Lansing, we can now speculate on factors that could have given rise to the acquisition of apple as a new host. At least three factors, apart from periodic failure of hawthorn trees to fruit, might have been involved. First, existing fruit on hawthorn trees may have been infested to such an extent, and received such an amount of fly marking pheromone deposited after egglaying, that females were stimulated to emigrate and fly considerable distances in search of unoccupied oviposition sites. Evidence suggests rapid fly emigration is a likely outcome in situations where most fruit are infested (Roitberg et al. 1982; Roitberg et al. 1985). Second, some of the females stimulated to emigrate may have been ones which, either because of genetic endowment or physiological state, had such a high egg load that oviposition was initiated in apple fruit. That physiological state can affect fly propensity to accept novel fruit has been demonstrated by Fitt (1986a), who showed that females of the Queensland fruit fly, Dacus tryoni Froggatt, oviposited readily into previously unacceptable fruit after several days without access to hosts. Third, the relative ability of an individual apple fruit to support many more larvae to maturity than an individual hawthorn fruit (Averill and Prokopy 1987) and the relatively much greater freedom of apple than hawthorn fruit from parasites of larvae (Diehl 1984; AliNiazee 1985) may have constituted a selective advantage to flies that oviposited in apple, despite the lesser ability of larval progeny to survive and grow in apple. In this regard, utilization of enemy free space has been proposed as an important factor leading to niche expansion in the evolution of many arthropods (Zwölfer 1975; Jeffries and Lawton 1984; Jaenike 1985a).

A rapidly growing body of literature demonstrates the existence of intraspecific phenotypic variation in host preference in herbivorous, parasitic, and saprophagous insects (reviewed by Fox and Morrow 1981; Papaj and Rausher 1983; Diehl and Bush 1984; Futuyma and Peterson 1985). Attempts to partition such variation into genetic and environmental (nonheritable) components have revealed several cases, in addition to the present example of $R$. pomonella, in which intraspecific variation in some facet of oviposition site selection has an apparent genetic basis (eg. Tabashnik et al. 1981; Wasserman and Futuyma 1981; Jaenike and Grimaldi 1983; Futuyma et al. 1984; Wasserman 1986; Jaenike 1986a) and several cases in which oviposition site selection is modified through prior egglaying experience (eg. Rausher 1978; Jaenike 1982, 1986b; Stanton 1984; Vet and van Opzeeland 1984; Hoffmann 1985; Traynier 1986; Papaj 1986). As with $R$. pomonella, evidence is lacking that larval environment has a measurable effect on the oviposition behavior of any herbivorous or saprophagous insect (eg. Tabashnik et al. 1981; Jaenike 1982; Papaj and Rausher 1983; Futuyma and Peterson 1985). It would seem that gathering empirical evidence on genetic and environmental components of host-associated mating site selection by males in conjunction with host-associated oviposition site selection by females would be an especially rewarding endeavor toward understanding processes leading to restriction in gene flow between conspecific populations. However, apart from the present study, this has been done only in rare instances (eg. Wood and Guttman 1982; Jaenike 1985b).

Numerous models have been proposed to explain host shifts in insects (eg. Bush 1975b; Felsenstein 1981; Bush 
and Diehl 1982; Rice 1984; Zwölfer and Bush 1984; Kondraskov and Mina 1986). Most models have focused on tight linkage relationships between genes involved in host selection by one or both sexes and genes involved in survival. However, as found here and as is the case in several other insects (eg. Wasserman and Futuyma 1981; Futuyma et al. 1984; Fitt 1986b; Hare and Kennedy 1986; Futuyma and Philippi 1987; but see van den Water 1983; Via 1986), a population or species may shift its host preference without any corresponding shift in physiological adaptation for survival on its new host. This type of pattern, apparently more common than previously thought, has led Futuyma (1983) to postulate that expansion of a population or species onto a new host may first involve genetic changes in behavioral aspects of host finding or acceptance and only subsequently involve selection favoring genes affecting survival and growth. Rausher (1984) has since developed a model that allows, under some circumstances, genetic-based variation in host preference within a population to be preserved indefinitely and therefore be present when genetic-based variation arises that promotes increased viability on the newly acquired host. Once both types of variation co-exist, preference and viability may evolve together to yield differentially adapted host races. To what extent the scenarios of Futuyma (1983) and Rausher (1984) might apply to the development of host races in $R$. pomonella remains to be determined.

Recently, S.H. Berlocher, G.L. Bush, J. Feder, and B.A. McPheron (unpub. data) have demonstrated significant electrophoretic differences between apple and hawthorn origin $R$. pomonella from sympatric populations at five sites in Illinois, two sites each in Wisconsin and Michigan, and one site in Washington, as well as between the Amherst apple and hawthorn populations studied here. This suggests at least some degree of restriction in gene flow between sympatric host-associated populations in other locales. Moreover, the data from Washington illustrate the rapidity with which differentiation between sympatric populations can occur, in that $R$. pomonella is estimated to have been present in Washington for less than 50 years (G.L. Bush, pers. communic.).

In the absence of more complete information, we hypothesize that the degree of differentiation between sympatric host-associated populations of $R$. pomonella may flow and ebb according to the structure of available high-quality host fruit resources over time and space within the local habitat. The findings in our study of Amherst and East Lansing populations may or may not be typical of populations elsewhere.

Acknowledgements. This study was supported by the Science and Education Administration of the USDA under grant 8200184 from the Competitive Research Grants Office, by NSF grant DEB 8109381, and by Massachusetts Agricultural Experiment Station Project 604 . We are grateful for the technical assistance of Susan Butkewich and Cynthia Kallet, manuscript typing by Julia Connelly, and the very helpful criticisms and suggestions of D.R. Papaj, S.B. Opp, G.L. Bush, D.J. Futuyma, J. Jaenike, S.H. Berlocher, B.A. McPheron and M.D. Rausher.

\section{References}

Ali Niazee MT (1985) Opiine parasitoids of Rhagoletis pomonella and $R$. zephyria in the Willamette Valley, Oregon. Can Entomol 117:163-166
Averill AL, Prokopy RJ (1987) Intraspecific competition in the tephritid fruit fly Rhagoletis pomonella. Ecology 68:878--886

Bush GL (1966) Taxonomy, cytology and evolution of the genus Rhagoletis in North America. Bull Harvard Mus Comp Zool 134:431-562

Bush GL (1974) The mechanism of sympatric host race formation in the true fruit flies. In: White MJD (ed) Genetic Mechanisms of Speciation in Insects. Australian and New Zealand Book Co., Sydney. pp 3-23

Bush GL (1975a) Modes of animal speciation. Ann Rev Ecol Syst $6: 339-364$

Bush GL (1975b) Sympatric speciation in phytophagous parasitic insects. In: Price PW (ed), Evolutionary Strategies of Parasitic Insects. Plenum Press, London, pp 187-206

Bush GL, Diehl SR (1982) Hort shifts, genetic models of sympatric speciation, and the origin of parasitic insect species. In: Visser JH, Minks AK (eds) Proc. 5th Intern. Symp. Insect-Plant Relationships, PUDOC, Wageningen, Netherlands, pp 297-305

Carle SA, Averill AL, Rule GS, Reissig WH, Roelofs WL (1987) Variation in host fruit volatiles attractive to apple maggot fly, Rhagoletis pomonella. J Chem Ecol 13:795-805

Chapman PJ (1933) Viability of eggs and larvae of the apple maggot (Rhagoletis pomonella). Cornell Univ Tech Bull 206:p 19

Diehl SR (1984) The role of host plant shifts in the ecology and speciation of Rhagoletis flies, Ph.D. thesis, Univ Texas p 256

Diehl SR, Bush GL (1984) An evolutionary and applied perspective of insect biotypes. Ann Rev Entomol 29:471-504

Diehl SR, Prokopy RJ (1986) Host selection behavior differences between the fruit fly sibling species Rhagoletis pomonella and R. mendax. Ann Entomol Soc Am 79:266-271

Diehl SR, Prokopy RJ, Henderson S (1986) The role of stimuli associated with branches and foliage in host selection by Rhagoletis pomonella. In: Cavalloro R (ed) Fruit Flies of Economic Importance, 84. A.A. Balkema, Rotterdam, pp 191-196

Fein BL, Reissig WH, Roelofs WL (1982) Identification of apple volatiles attractive to the apple maggot, Rhagoletis pomonella. J Chem Ecol 8:1473-1487

Felsenstein J (1981) Skepticism toward Santa Rosalia, or why are there so few kinds of animals? Evolution 35:124-135

Fisher RA (1954) Statistical Methods for Research Workers. 12th ed. Oliver and Boyd, Edinburgh

Fitt GP (1986a) The influence of a shortage of hosts on the specificity of oviposition behavior in species of Dacus. Physiol Entomol 11:133-143

Fitt GP (1986b) The roles of adult and larval specialization in limiting the occurrence of five species of Dacus in cultivated fruits. Oecologia 69:101-109

Fox LR, Morrow PA (1981) Specialization: species property or local phenomenon? Science 211:887-893

Futuyma DJ (1983) Selective factors in the evolution of host choice by phytophagous insects. In: Ahmad SA (ed) Herbivorous Insects: Host Seeking Behavior and Mechanisms. Academic Press, New York, pp 227-244

Futuyma DJ, Mayer GC (1980) Non-allopatric speciation in animals. Syst Zool 29:254-271

Futuyma DJ, Peterson SC (1985) Genetic variation in the use of resources by insects. Ann Rev Entomol 30:217-238

Futuyma DJ, Philippi TE (1987) Genetic variation and covariation in responses to host plants by Alsophila pometaria. Evolution $41: 269-279$

Futuyma DJ, Cort RP, Van Noordwijk I (1984) Adaptation to host plants in the fall cankerworm (Alsophila pometaria) and its bearing on the evolution of host affiliation in phytophagous insects. Am Nat 123:287-296

Girolami V, Strapazzon A, Crnjar R, Angioy AM, Pietra P, Stoffolano JG, Prokopy RJ (1986) Behavior and sensory physiology of Rhagoletis pomonella in relation to oviposition sitmulants and deterrents in fruit. In: Cavalloro R (ed) Fruit Flies of Economic Importance, 84. A.A. Balkema, Rotterdam, pp 183 190

Goodman LA (1964) Simultaneous confidence intervals for con- 
trasts among multinomial populations. Ann Math Stat 35:716-725

Grizzle JE, Starmer CF, Koch GG (1969) Analysis of categorical data by linear models. Biometrics 25:489-504

Hall JA (1939) Further observations on the biology of the apple maggot (Rhagoletis pomonella). Ann Rept Entomol Soc Ontario $69: 53-58$

Hall JA (1943) Notes on the dogwood fly, a race of Rhagoletis pomonella. Can Entomol 75:202-203

Hare JD, Kennedy GC (1986) Genetic variation in plant-insect associations: survival of Leptinotarsa decemlineata populations on Solanum carolinense. Evolution 40:1031-1043

Hoffmann AA (1985) Effects of experience on oviposition and attraction in Drosophila: comparing apples and oranges. Am Nat 126:41-51

Jaenike J (1981) Criteria for ascertaining the existence of host races. Am Nat 117:830-834

Jaenike J (1982) Environmental modification of oviposition behavior in Drosophila. Am Nat 119:784-802

Jaenike J (1985a) Parasite pressure and the evolution of amanitin tolerance in Drosophila. Evolution 39:1295-1301

Jaenike J (1985b) Genetic and environmental determinants of food preference in Drosophila tripunctata. Evolution 39:362--369

Jaenike J (1986a) Genetic complexity of host-selection behavior in Drosophila. Proc Nat Acad Sci 83:2148-2151

Jaenike J (1986b) Intraspecific variation for resource use in Drosophila. Biol J Linn Soc 27:47-56

Jaenike J, Grimaldi D (1983) Genetic variation for host preference within and among populations of Drosophila tripunctata. Evolution 37:1023-1033

Jeffries MJ, Lawton JH (1984) Enemy free space and the structure of ecological communities. Biol J Linn Soc 23:269-286

Jorgensen CD, Allred DB, Westcott RL (1986) Apple maggot adaptation for cherries in Utah. Great Basin Nat 46:173-174

Koch GG, Amara IA, Davis GW, Gillings DB (1982) A review of some statistical methods for covariance analysis of categorical data. Biometrics 38:563-595

Kondrashov AS, Mina MV. (1986) Sympatric speciation: when is it possible? Biol J Linn Soc 27:201-223

Maxwell CW, Parsons EC (1968) The recapture of marked apple maggot adults in several orchards from one release point. J Econ Entomol 61:1157-1159

Mayr E (1970) Populations, Species, and Evolution. Harvard Univ Press, Cambridge

Miller JR, Strickler KL (1984) Finding and accepting host plants. In: Bell WJ, Carde RT (eds) Chemical Ecology of Insects. Chapman and Hall, London, pp 127-157

Moericke V, Prokopy RJ, Berlocher S, Bush GL (1975) Visual stimuli eliciting attraction of Rhagoletis pomonella flies to trees. Entomol Exp Appl 18:497-507

Opp SB, Prokopy RJ (1986) Variation in laboratory oviposition by Rhagoletis pomonella in relation to mating status. Ann Entomol Soc Am 79:705-710

Owens ED, Prokopy RJ (1986) Relationship between reflectance spectra of host plant surfaces and visual detection of host fruit by Rhagoletis pomonella flies. Physiol Entomol 11:297-307

Papaj DR (1986) Shifts in foraging behavior by a Battus philenor population: field evidence for switching by individual butterflies. Behav Ecol Sociobiol 19:31-39

Papaj DR, Prokopy RJ (1986) Phytochemical basis of learning in Rhagoletis pomonella and other herbivorous insects. $\mathrm{J}$ Chem Ecol 12:1125-1143

Papaj DR, Rausher MD (1983) Individual variation in host location by phytophagous insects. In: Ahmad S (ed) Herbivorous Insects: Host Seeking Behavior and Mechanisms. Academic Press, New York, pp 77-124

Paterson HEH (1981) The continuing search for the unknown and unknowable: a critique of contemporary ideas on speciation. South African J Sci 77:113-119

Pickett AD (1937) Studies on the genus Rhagoletis with special reference to Rhagoletis pomonella. Canad J Res 15:53-75
Pickett AD, Neary ME (1940) Further studies on Rhagoletis pomonella. Scient Agric 20:551-556

Pree DJ (1977) Resistance to development of larvae of the apple maggot in crab apples. J Econ Entomol 70:611-614

Prokopy RJ (1966) Artificial oviposition devices for apple maggot. J Econ Entomol 59:231-232

Prokopy RJ (1968) Visual responses of apple maggot flies, Rhagole tis pomonella: orchard studies. Entomol Exp Appl 11:403422

Prokopy RJ (1972) Evidence for a marking pheromone deterring repeated oviposition in apple maggot flies. Environ Entomol $1: 326-332$

Prokopy RJ (1977) Attraction of Rhagoletis flies to red spheres of different sizes. Canad Entomol 109:593-596

Prokopy RJ (1981) Oviposition-deterring pheromone system of apple maggot flies. In: Mitchell ER (ed) Management of Insect Pests with Semiochemicals. Plenum Publ Co, New York, pp 477-494

Prokopy RJ, Berlocher SH (1980) Establishment of Rhagoletis pomonella on rose hips in southern New England. Canad Entomol $51: 1319-1320$

Prokopy RJ, Bush GL (1972) Apple maggot infestation of pear. J Econ Entomol 65:597

Prokopy RJ, Bush GL (1973) Ovipositional responses to different sizes of artificial fruit by flies of Rhagoletis pomonella species group. Ann Entomol Soc Am 66:927-929

Prokopy RJ, Bennett EW, Bush GL (1971) Mating behavior in Rhagoletis pomonella. I. Site of assembly. Canad Entomol 103:1405-1409

Prokopy RJ, Moericke V, Bush GL (1973). Attraction of apple maggot flies to odor of apples. Envir Entomol 2:743-749

Prokopy RJ, Averill AL, Cooley SS, Roitberg CA, Kallet C (1982a) Variation in host acceptance pattern in apple maggot flies. In: Visser JH, Minks AK (eds) Proc. 5th Intern. Symp. Insect-Plant Relationships, PUDOC, Wageningen, Netherlands, pp 123-129

Prokopy RJ, Averill AL, Cooley SS, Roitberg CA (1982b) Associative learning in egglaying site selection by apple maggot flies. Science 218:76-77

Prokopy RJ, Kallet C, Cooley SS (1985) Fruit acceptance pattern of Rhagoletis pomonella flies from different geographic regions. Ann Entomol Soc Am 78:799-803

Prokopy RJ, Papaj DR, Cooley SS, Kallet C (1986) On the nature of learning in oviposition site acceptance by apple maggot flies. Anim Behav 34:98-107

Prokopy RJ, Aluja M, Green TA (1987) Dynamics of host odor and visual stimulus interaction in host finding behavior of apple maggot flies. In: Labeyrie V, Fabres G, Lachaise D (eds) Insects-Plants, Junk, Netherlands, pp 161-166

Rausher MD (1978) Search image for leaf shape in a butterfly. Science 200:1071-1073

Rausher MD (1984) The evolution of habitat preference in subdivided populations. Evolution 38:596-608

Reissig WH (1979) Survival of apple maggot larvae, Rhagoletis pomonella, in picked and unpicked apples. Canad Entomol 111:181-187

Reissig WH, Smith DC (1978) Bionomics of Rhagoletis pomonella in Crataegus. Ann Ent Soc Am 71:155-159

Rice WR (1984) Disruptive selection on habitat preference and the evolution of reproductive isolation: a simulation study. Evolution 38:1251-1260

Robert P (1985) A comparative study of some aspects of the reproduction of three Caryedon serratus strains in presence of its potential host plants. Oecologia $65: 425-430$

Roitberg BD, Cairl RS, Prokopy RJ (1985) Oviposition deterring pheromone influences dispersal distance in tephritid fruit flies. Entomol Exp Appl 35:217-220

Roitberg BD, Van Lenteren JC, Van Alphen JJM, Galis F, Prokopy RJ (1982) Foraging behavior of Rhagoletis pomonella, a parasite of hawthorn (Crataegus), in nature. J Anim Ecol $51: 307-325$ 
SAS Institute (1985) SAS user's guide: statistics: version 5. SAS Institute, Cary, N.C.

Shervis LJ, Boush GM, Koval CF (1970) Infestation of sour cherries by the apple maggot: confirmation of a previously uncertain host status. J Econ Entomol 63:294-295

Smith DC, Prokopy RJ (1980) Mating behavior of Rhagoletis pomonella. VI. Site of early-season encounters. Canad Entomol 112:585-590

Stanek EJ III, Diehl SR, Dgetluck M, Stokes ME, Prokopy RJ (1987) Statistical methods for analyzing discrete responses of insects tested repeatedly. Environ Entomol 16:319-326

Stanton ML (1984) Short-term learning and the searching accuracy of egglaying butterflies. Anim Behav 32:33-40

Tabashnik BE, Wheelock H, Rainbolt JD, Watt WB (1981) Individual variation in oviposition preference in the butterfly, Colias eurytheme. Oecologia 50:225-230

Traynier RMM (1986) Visual learning in assays of sinigrin solution as an oviposition releaser for the cabbage butterfly, Pieris rapae. Entomol Exp Appl 40:25-33

Van den Water TPM (1983) A host race of the small ermine moth Yponomeuta padellus in Northern Europe. Netherlands J Zool 33:276-282

Vet LEM, Van Opzeeland K (1984) The influence of conditioning of olfactory microhabitat and host location in Asobara tabida and $A$. rufescens larval parasitoids of Drosophilidae. Oecologia 63:171-177

Via S (1986) Genetic covariance between oviposition preference and larval performance in an insect herbivore. Evolution 40:778-785

Walsh BD (1867) The apple worm and the apple maggot. J Hort $2: 338-343$

Wasserman SS (1986) Genetic variation in adaptation to foodplants among populations of the southern cowpea weevil, Callosobruchus maculatus: evolution of oviposition preference. Entomol Exp Appl 42:201-212

Wasserman SS, Futuyma DJ (1981) Evolution of host plant utilization in laboratory populations of the southern cowpea weevil, Callosobruchus maculatus. Evolution 35:605-617

Wood TK, Guttman SI (1982) Ecological and behavioral basis for reproductive isolation in the sympatric Enchenopa binota complex. Evolution 36:233-242

Zwölfer H (1975) Artbildung und ökologische Differenzierung bei phytophagen Insekten. Verk Deutschen Zool Gesell 67:394-401

Zwölfer H, Bush GL (1984) Sympatrische and parapatrische Artbildung. Z Zool Syst Evol Forsch 22:211-233

Received January 4, 1988 